\title{
Motivasi Berjilbab Mahasiswi Universitas Al Azhar Indonesia (UAI)
}

\author{
Radhiya Bustan ${ }^{1}$, Abdullah Hakam Shah ${ }^{2}$ \\ ${ }^{1}$ Program Studi Psikologi, Fakultas Psikologi dan Pendidikan \\ ${ }^{2}$ Program Studi Healing \& Counseling, Fakultas Psikologi dan Pendidikan \\ Universitas Al Azhar Indonesia, Jl. Sisingamangaraja, Jakarta 12110 \\ Penulis untuk korespondensi/E-mail: $\underline{\text { radhiya_bustan@uai.ac.id }}$
}

\begin{abstract}
Abstrak - Titik tolak penelitian ini adalah untuk menelusuri secara ilmiah motivasi berjilbab mahasiswi UAI -khususnya mereka yang berjilbab setelah masuk UAI, pengetahuan mereka tentang syariat jilbab, dan manfaat yang mereka peroleh. Diharapkan, hasilnya dapat membantu pimpinan dan segenap civitas akademika UAI, serta orang tua mahasiswi dalam membangun pendidikan karakter dan lingkungan keagamaan yang kondusif. Penelitian ini menyimpulkan sejumlah temuan penting, di antaranya: (1) Para mahasiswi UAI yang berjilbab secara garis besar bisa dikategorikan ke dalam dua kelompok: konsisten dan inkonsisten. (2) Konsistensi mereka dalam berjilbab sangat dipengaruhi motivasi intrinsik yang kuat. (3) Mahasiswi UAI yng berjilbab mendapat dukungan dari keluarga, teman-teman kuliah, dan orang terdekatnya. Dan motivasi ekstrinsik ini sangat membantu dalam kasus di mana motivasi intrinsiknya tidak begitu kuat.
\end{abstract}

Abstarct - The main purpose of this research is to explore scientifically the motivation behind wearing hijab among UAI students - particulary those who decide to wear hijab after entering the UAI, their syariah knowledge about the obligation of wearing hijab, and what the benefit is. The result is expected to help the leaders and academic community in the UAI, as well as parents in building character and strengthening religious environment. The study summarizes a number of important findings: (1) Basically, the UAI students can be categorized into two groups; consistent and inconsistent in wearing hijab. (2) Their consistency in wearing hijab briefly influenced by its strong intrinsic motivation. (3) Students who wear hijab get strong support from the family, friends, and people who close to them. This extrinsic motivation can be very helpful where intrinsic motivation is not strong enough.

\section{PENDAHULUAN}

$\mathrm{S}^{\mathrm{a}}$ alah satu indikator keislaman seorang muslimah yang secara eksplisit disebutkan dalam al-Quran dan Hadits adalah pilihannya untuk mengenakan jilbab secara istiqamah (konsisten). Selain merupakan bentuk kepatuhan menjalankan syariat Allah SWT, dalam Qs. al-Ahzab: 53 dan Qs. alNuur: 31 disebutkan beberapa manfaat serta hikmah berjilbab. Diantaranya: meneguhkan identitas sebagai muslimah, menjaga kehormatan diri dan orang lain yang melihatnya, memelihara rasa malu, dan sebagainya.

Di Indonesia, sebelum paruh kedua tahun 90-an, jilbab masih merupakan fenomena yang kurang familiar di tengah-tengah masyarakat. Secara eksternal, selain dikarenakan kebijakan pemerintah Orde Baru yang kurang memberi ruang bagi muslimah untuk berjilbab, khususnya bagi para pelajar dan pegawai negeri sipil; perlakuan lingkungan pun acap diskriminatif terhadap muslimah berjilbab [1].

Di luar faktor eksternal tersebut, menurut Asma Nadia, terdapat faktor internal yang juga kuat mempengaruhi, seperti kurangnya kesadaran keislaman, tidak berani mengambil keputusan drastis, takut tidak bisa konsisten, sampai pada anggapan berjilbab dapat menyebabkan jauh jodoh [2].

Namun sejak paruh kedua tahun 90-an jilbab menjadi trend yang semakin populer. Tidak hanya di kalangan ibu-ibu pengajian, pelajar tingkat SMP, SMA hingga mahasiswi, bahkan wanita karir yang berjilbab sangat mudah ditemui di hampir seluruh wilayah Indonesia. Komunitas muslimah berjilbab, 
seperti Hijabers Community, bermunculan terutama di kota-kota besar. Hal ini menjadi motivasi tersendiri baik bagi yang sudah berjilbab sehingga lebih percaya diri, bagi yang belum berjilbab tetapi mulai tertarik untuk berjilbab, maupun bagi yang belum tergerak berjilbab untuk tahu lebih jauh tentang pernik-pernik dan 'suka-duka' berjilbab.

Tren ini juga terlihat di lingkungan Universitas Al Azhar Indonesia (UAI). Sekalipun peraturan tentang busana di UAI sebatas berpakaian sopan, tanpa mewajibkan berjilbab bagi civitas akademika yang muslimah (P3EK, 2012); tetapi tidak sedikit mahasiswi UAI yang dengan kesadaran sendiri memilih berjilbab secara istiqamah. Bahkan, mereka telah membentuk komunitas yang mereka namakan: UAI Hijab Community (Lihat:

http://www.youtube.com/watch?v=y4i5w7sHeC0).

Dalam konteks UAI sebagai lembaga pendidikan tinggi yang lahir di lingkungan masjid dan menjadikan keislaman sebagai salah satu jati diri utamanya, fenomena motivasi berjilbab para mahasiswi ini -khususnya, yang baru berjilbab setelah masuk UAI - menarik untuk ditelusuri lebih dalam lewat suatu penelitian ilmiah. Sebab ini juga terkait dengan pembentukan lingkungan yang kondusif, serta proyeksi dan evaluasi pendidikan karakter di lingkungan UAI.

\section{PERMASALAHAN}

Penelitian ini bermaksud menelaah poin-poin sebagai berikut:

1. Bagaimana pengetahuan mahasiswi UAI mengenai jilbab?

2. Apa motivasi para mahasiswi UAI ketika mereka memutuskan untuk berjilbab?

3. Apa manfaat yang diperoleh mahasiswi UAI setelah berjilbab?

\section{TUJUAN DAN MANFAAT PENELITIAN}

Tujuan dari penelitian ini adalah mengetahui wawasan mahasiswi UAI mengenai jilbab, motivasi yang menggerakkan para mahasiswi UAI berjilbab, khususnya mereka yang memilih berjilbab setelah masuk UAI; serta untuk mengetahui manfaat apa yang mereka peroleh setelah memakai jilbab?

Adapun manfaat dari penelitian ini, secara praktis, adalah memberikan informasi yang dapat membantu pimpinan dan segenap civitas akademika
UAI, serta orang tua mahasiswi yang concern terhadap upaya pembentukan karakter. Sedangkan secara teoritis, penelitian ini dapat memberikan sumbangan pengetahuan tentang teori-teori yang berkaitan dengan motivasi perilaku keagamaan di kalangan remaja puteri.

\section{KAJIAN TEORITIK}

\section{Motivasi}

Istilah motivasi berasal dari bahasa Latin, yang berarti "bergerak". Motivasi adalah suatu proses dalam diri manusia atau hewan yang menyebabkan organisme tersebut bergerak menuju tujuan yang dimiliki, atau bergerak menjauh dari situasi yang tidak menyenangkan [3]. Motif-motif tersebut dapat berupa motif untuk memenuhi kebutuhan biologis, seperti dorongan-dorongan untuk mendapatkan makanan dan minuman, untuk menghindari suhu yang tidak menyenangkan, rasa sakit, dan lain-lain; atau motif untuk memenuhi kebutuhan psikologis.

Menurut King, Laura A, Motivasi (motivation) adalah kekuatan yang menggerakkan seseorang untuk berperilaku, berpikir, dan merasa seperti yang mereka lakukan. Perilaku yang termotivasi diberi kekuatan, diarahkan, dan dipertahankan [4].

Menurut Mc Donald, motivasi adalah perubahan energi dalam diri seseorang yang ditandai dengan munculnya feeling, dan didahului dengan tanggapan terhadap adanya tujuan.

Menurut King, Laura A [4], motivasi dapat berupa:

1. Motivasi intrinsik (intrinsic motivation)

Merupakan suatu keinginan untuk melakukan suatu aktivitas atau meraih pencapaian tertentu semata-mata demi kesenangan atau kepuasan yang didapat dari melakukan aktivitas tersebut. Motivasi intrinsik didasarkan pada faktor-faktor internal, seperti kebutuhan organismik (otonomi, kompetensi, dan keterhubungan seperti rasa ingin tahu, tantangan, dan usaha), aktualisasi diri, dan sebagainya. Ketika kita termotivasi secara intrinsik, kita terlibat dalam perilaku karena kita menikmatinya.

2. Motivasi ekstrinsik (extrinsic motivation) Merupakan keiginan untuk mengejar suatu tujuan yang diakibatkan oleh imbalan-imbalan eksternal seperti penguatan (reward) dan hukuman (punisment). Ketika kita termotivasi secara ekstrinsik, maka kita terlibat dalam perilaku tertentu karena ganjaran eksternal, seperti pujian orang lain, menghindari 
kekecewaan orang tua, melindungi diri, dan lainnya.

Dari berbagai pendapat diatas, dapat disimpulkan bahwa motivasi merupakan daya atau kekuatan yang mampu mendorong, merangsang, menggerakkan, membangkitkan sebuah tingkah laku. Motivasi berjilbab dalam penelitian ini melihat penyebab-penyebab atau alasan mahasiswi Universitas Al Azhar Indonesia (UAI) untuk menggunakan jilbab, apakah dipengaruhi oleh motivasi instrinsik yang bertujuan untuk kepuasan dari dalam diri, ataukah untuk mengejar suatu tujuan mendapat imbalan eksternal.

\section{Definisi Jilbab}

Secara ethimologis, jilbab biasa didefinisikan sebagai: (1) kain panjang yang dipakai wanita untuk menutup kepala, bahu, dan kadang-kadang muka. (2) rajutan panjang yang ditempelkan pada topi atau tutup kepala wanita [5].

The Encyclopedia of Islam (1986) menyebutkan sejumlah istilah Arab yang bisa digunakan sebagai padanan kata jilbab seperti dipahami kaum muslim Indonesia: burqa', 'abayah, tarhah, burnus, jellabah, hayik, milayah, gallabiyah, disydasya, gargush, gina, mungub, litsmah, yashmik, habarah, izar. Namun sebenarnya tidak semua istilah tersebut sepadan dengan kata jilbab. Sebab beberapa di antaranya lebih bermakna cadar (kain penutup muka), seperti burqa', niqab, dan litsmah.

Menurut Bahtiar \& Deni Sutan [6], berbagai makna jilbab diantaranya adalah:

1. Imam Raghib, ahli kamus Al-Qur'an yang terkenal, mengartikan jilbab sebagai pakaian yang longgar yang terdiri atas baju panjang dan kerudung yang menutup badan kecuali muka dan telapak tangan.

2. Imam Al-Fayumi, salah satu penyusun kamus Arab mengatakan, bahwa jilbab adalah pakaian yang lebih longgar dari kerudung, tetapi tidak seperti selendang.

3. Ibnu Mansur juga mengatakan, jilbab adalah selendang atau pakaian lebar yang dipakai perempuan untuk menutupi kepala, punggung, dan dada.

4. A. Hassan ahli tafsir mengatakan, bahwa jilbab adalah pakaian yang menutup segenap badan atau sebagian dari badan sebelah atas.

5. H.B Jassin salah satu tokoh intelektual menuturkan, jilbab adalah baju kurung yang menutup kepala, muka, dan dada.
6. Prof. Quraish Shihab mengartikan sebagai, baju kurung yang longgar dilengkapi dengan kerudung penutup kepala.

7. Ibnu Manzhur mendefinisikan jilbab sebagai selendang atau pakaian lebar yang dipakai perempuan untuk menutupi kepala, punggung, dan dada.

8. J.S Badudu mengartikan jilbab sebagai sejenis pakaian perempuan yang hampir menutupi seluruh tubuhnya, yang terbuka hanya wajah dan tangan.

9. Tim penyusun Kamus Pusat Pembinaan dan Pengembangan Bahasa mengartikan jilbab sebagai baju kurung yang longgar, dilengkapi dengan kerudung, yang menutupi seluruh tubuhnya, yang terbuka hanya wajah dan tangan.

10. Dewan Redaksi Ensiklopedi Islam mendefinisikan jilbab sebagai sejenis baju kurung yang lapang yang dapat menutup kepala, muka, dan dada.

Berdasarkan beberapa pengertian diatas dapat disimpulkan bahwa jilbab adalah pakaian wanita yang longgar yang dapat menutup kepala, muka, dan dada. Akan tetapi jika makna kata jilbab itu kita tarik dalam konteks keIndonesiaan saat ini, maka pemahaman terhadap jilbab adalah sebagian dari unsur busana seorang wanita yang biasa dikenakan untuk menutupi bagian kepala dengan bentuk dan pola tertentu.

\section{Tujuan dan Fungsi Berjilbab}

Tujuan berbusana dalam Islam ada dua: pertama untuk menutup aurat, dan kedua untuk berhias. Karena itulah Allah SWT memberi anugerah kepada manusia pakaian dan perhiasan yang telah disediakan dengan pengelolaannya. Dengan demikian, maka pakaian itu memiliki empat fungsi, yaitu:

1. Melindungi aurat

2. Melindungi tubuh dari panas dan dingin

3. Menjaga dan melindungi kesucian, kehormatan, dan kemuliaan sebagai seorang perempuan

4. Untuk menjaga identitas sebagai perempuan muslimah yang membedakan dengan perempuan lain (Muhyidin dalam Ruliana, 2010).

Menurut Ruliana [7], secara garis besar jilbab berfungsi sebagai:

1. Pembeda, jilbab akan membedakan seorang wanita yang memiliki kehormatan dari yang lainnya. Wanita berjilbab harus menjadi contoh kepada setiap wanita baik yang berjilbab atau tidak. 
2. Pembentuk perilaku, jilbab bisa mengarahkan tingkah laku orang yang memakainya. Jilbab yang dikenakan karena kesadaran iman, akan mampu mengontrol setiap sikap dan tindakan yang menjurus kepada maksiat.

3. Pembentuk emosi, jilbab bisa menumbuhkan rasa cinta dan benci, marah atau sayang, suka ataupun tidak suka. Dia akan lebih mudah menumbuhkan perasaan yang positif terhadap sesamanya bila dibandingkan dengan yang tidak memakai jilbab.

Dengan demikian seorang muslimah yang mengenakan jilbab akan merasakan ketenangan di dalam hatinya. Karena pertama, dia sudah menjalankan syarieeah Islam yang telah dibebankan kepadanya. Kedua, merasa aman dan tentram dari gangguan orang-orang jahil dan orang-orang yang suka memfitnah. Ketiga, dia akan bisa menjaga emosinya apabila akan melakukan perbuatan keji, seperti: mencuri, berbicara kotor, berbohong dan lain sebagainya.

Dari ketiga fungsi jilbab diatas (pembeda, perilaku, dan emosi) itu semuanya saling berhubungan dan saling melengkapi satu sama lain. Jadi, tingkah laku yang sopan dan iman yang kuat, serta mampu mengontrol emosi, sekaligus perlu dimiliki oleh perempuan muslimah.

\section{METODOLOGI PENELITIAN}

\section{Jenis Penelitian}

Penelitian ini dilakukan dengan metode kualitatif, karena peneliti ingin mendapat gambaran menyeluruh mengenai motivasi mahasiswa Universitas Al Azhar Indonesia dalam menggunakan jilbab. Menurut Creswell dalam Santoso \& Royanto, penelitian kualitatif merupakan suatu proses memperoleh pemahaman tentang masalah sosial atau manusia, yang diselenggarakan dalam setting penelitian yang alamiah, berdasarkan gambaran yang dibangun secara kompleks dan menyeluruh dari pandangan-pandangan yang dikemukakan secara rinci oleh partisipan [8].

\section{Subyek Penelitian}

Subyek dalam penelitian ini adalah 3 orang mahasiswi Universitas Al Azhar Indonesia (UAI) yang baru memakai jilbab ketika kuliah di UAI. Pemilihan subyek ini memperhatikan faktor lingkungan tempat tumbuh, seperti tingkat keislaman keluarga dan sejarah pendidikan sehingga merepresentasikan heterogenitas mahasiswi UAI.

\section{Prosedur Penelitian}

Secara garis besar penelitian ini dilakukan dalam 3 tahapan, yaitu:

a. Persiapan penelitian, hal-hal yang perlu dipersiapkan untuk penelitian ini adalah mendata subyek penelitian. Hal lain yang perlu dipersiapkan adalah mempersiapkan panduan wawancara dan observasi.

b. Pelaksanaan penelitian. Penelitian ini dilaksanakan di Universitas Al Azhar Indonesia (UAI) pada bulan Maret sampai Juli 2013.

c. Pelaporan penelitian. Tahap ini adalah tahap akhir dengan melakukan pengolahan data dan membuat hasil penelitian dalam bentuk laporan.

\section{Teknik Pengumpulan Data}

Pengumpulan data dalam penelitian ini dilakukan dengan berbagai cara, yaitu:

1. Wawancara. Teknik wawancara yang digunakan dalam penelitian ini adalah wawancara mendalam (in-depth interview), yaitu proses memperoleh keterangan untuk tujuan penelitian dengan cara tanya jawab sambil bertatap muka antara pewawancara dengan orang yang diwawancarai, dengan atau tanpa menggunakan pedoman (guide) wawancara (Saryono \& Anggareni, 2010).

2. Observasi. Peneliti menggunakan teknik observasi agar dapat mengamati secara realistik motivasi apa yang membuat mahasiswa UAI memakai jilbab.

3. Dokumentasi. Dokumentasi diperlukan agar peneliti dapat memperoleh data lainnya yang tersimpan dalam bentuk dokumen seperti catatan harian, surat-surat pribadi, foto, dan lain sebagainya.

4. Triangulasi/gabungan. Menggabungkan berbagai sumber informasi dan metode agar dapat melengkapi data dan sebagai sarana untuk verifikasi hasil yang diperoleh.

\section{Instrumen Penelitian}

Instrumen yang digunakan dalam penelitian ini adalah:

1. Peneliti sebagai instrumen utama, karena keterampilan peneliti untuk menggali informasi dan menginterpretasikan hasil penelitian.

2. Pedoman wawancara, dibuat dalam bentuk pertanyaan terbuka agar dapat memancing jawaban secara lebih bebas berdasarkan kacamata, pengalaman, dan keinginan-keinginan partisipan yang diteliti. 
3. Lembar observasi, dibuat dalam bentuk behavior check list, agar dapat memperoleh gambaran perilaku-perilaku yang muncul dari partisipan yang menggambarkan perasaan maupun pengalaman kesehariannya.

4. Alat perekam dan kamera untuk membantu peneliti merekam informasi dan situasi yang relevan dengan penelitian.

5. Alat tulis untuk mencatat hasil wawancara dan mengamatan yang dilakukan terhadap partisipan.

\section{Analisis Data}

Metode analisis yang digunakan dalam penelitian ini adalah:

1. Pengaturan/penataan data

Sebelum mulai menganalisis data, peneliti memastikan bahwa semua data telah lengkap, tercatat dan diberi label dengan sistematis, sehingga data menjadi teratur.

2. Melakukan koding dan kategorisasi.

Peneliti menyusun kata kunci, tema, isu, dan pernyataan-pernyataan partisipan. Inti koding adalah menemukan dan membandingkan persamaan serta perbedaan materi data untuk membuat susunan kategori [9].

3. Mencari pola dan proposisi penelitian

Kemudian peneliti mengelompokkan kategori yang berbeda-beda menjadi tema-tema besar sehingga lebih stabil, rapi, logis, dan masuk akal.

4. Menafsirkan data

5. Mengevaluasi penafsiran

Pada tahap ini peneliti melakukan verifikasi dan validasi terhadap keabsahan data, kemudian merefleksikannya terhadap interpretasi.

\section{HASIL DAN PEMBAHASAN}

Data yang telah diperoleh disajikan dalam dua bentuk analisis; yaitu analisis tiap subyek, dan analisis antar subyek.

Analisis tiap sukyek meliputi gambaran umum masing-masing subjek penelitian, pengetahuan subyek mengenai jilbab, motivasi internal dan eksternal masing-masing subyek, serta manfaat berjilbab menurut subyek. Pokok bahasan ini dikaitkan dengan tujuan penelitian dan pendekatan teori motivasi King, Laura A(2010).

\section{Analisis Tiap Subyek}

\section{Gambaran Umum Subjek D}

D adalah mahasiswi semester 7 (tujuh) di Universitas Al Azhar Indonesia (UAI). Anak sulung dari keluarga PNS yang tinggal di kompleks pegawai Sekretariat Negara. Mengenyam pendidikan dasar dan menengah pertama di sekolah swasta yang sangat memperhatikan pendidikan Islam kepada anak-anak didiknya. Khusus SMP tempatnya belajar dulu, D bahkan menggambarkannya sebagai lembaga pendidikan dengan lingkungan yang sangat mendukung sekali bagi penanaman nilai-nilai keislaman. "Apa yg diberikan saat SMP mengenai agama Islam sangat banyak mempengaruhi pola pikir dan membuat saya ingin selalu dekat dengan Allah," ujarnya dalam suatu wawancara yang diadakan tanggal 27 Juli 2013.

Setamat SMP, D melanjutkan pendidikan di SMU Negeri yang awalnya merupakan sekolah Katholik. Walaupun pendidikan agama Islam tidak terlalu ditekankan di SMU Negeri ini, D masih bisa mengimbanginya dengan aktif dalam kegiatan ekstra kurikuler Rohis. Sehingga ajaran keislaman yang banyak didapatkannya di bangku SMP tidak pudar.

Keluarga D awalnya tidak terlalu kuat menerapkan tuntunan Islam. Malah, menurut ingatan masa kecil D, keluarganya cenderung kejawen. Tetapi setelah kedua orang tuanya menunaikan ibadah haji, beliau berdua mulai serius mendalami Islam. Dan itu berlanjut sampai sekarang. "Alhamdulillah, sekarang unsur kejawennya sedikit demi sedikit hilang dalam keluarga saya, dan lebih menjadi keluarga Islami yang sebenarnya," tutur D.

D adalah sosok remaja yang supel, cukup perhatian kepada keluarga besar dan teman-temannya. Walaupun, menurut deskripsi teman akrabnya, D terkadang terlihat plinplan.

\section{Pengetahuan Mengenai Jilbab Subjek D}

Pengetahuan D tentang syariat Islam cukup baik. Ia tidak menganggap berjilbab sekadar bagian dari budaya yang ada di sejumlah komunitas muslim. Berjilbab, menurutnya, lebih merupakan perintah Allah SWT. yang kemudian menjadi salah satu identitas muslimah yang membudaya di tengahtengah masyarakat.

Dalam wawancara yang dilakukan hari Ahad, 28 Juli 2013, D menyampaikan: "Jilbab bukan cuma budaya, tetapi lebih sebagai perintah Allah SWT. agar muslimah menutup aurat mereka. Yaitu, bagian-bagian tubuh yang tidak boleh diperlihatkan kepada banyak orang- yang bukan mahramnya." 
Walaupun belum bisa sepenuhnya mengamalkan, D juga mengetahui bahwa jilbab yang sesuai dengan syariat Islam adalah yang menutup aurat dengan sempurna, dan tidak menempel ketat di tubuh pemakainya.

Tentang pemahaman keislaman D, MF sahabat dekatnya menggambarkan: "D bukan seorang yang mendapat pengetahuan agama yang banyak, tetapi cukup. D lebih suka berpikir secara logis tentang hubungan antara ajaran agama dengan realitas kehidupan yang ada." (Wawancara dengan MF, Jumat, 02 Agustus 2013)

Dengan model pergaulan remaja saat ini, khususnya di kota-kota besar, menanamkan kebiasaan berjilbab dalam pengalaman $\mathrm{D}$ sendiri tidak mudah. Oleh karena itu, menurutnya, sekalipun jilbab itu wajibnya setelah baligh namun kalau bisa diperkenalkan sejak anak perempuan itu masih kecil.

Pengetahuan D yang cukup baik mengenai syariat Islam, khususnya terkait kewajiban berjilbab, belum membuat D sepenuhnya berjilbab. D tampak masih berproses untuk bisa konsisten yang sesuai dengan syariat Islam.

\section{Motivasi Instrinsik Subjek D}

D sebenarnya mulai terpikir untuk memakai jilbab sejak duduk di bangku SMP. Namun tarik-menarik antara Lingkungan sekolah yang sangat kondusif menanamkan nilai-nilai Islam dengan lingkungan keluarga yang cenderung kejawen, membuat apa yang terlintas di benaknya untuk berjilbab tidak kunjung terwujud.

Ketika memakai ke sekolah dulu, D tidak merasakan adanya keterpaksaan. Ia justru merasa nyaman dengan jilbab yang dikenakannya. D juga merasa bahwa dengan berjilbab ia menjadi pribadi yang lebih mampu bertanggung jawab dengan menjaga lisan dan perilakunya. MF juga berpendapat bahwa proses $\mathrm{D}$ berjilbab tidak sulit, malah cenderung mudah.

Keinginan D untuk berjilbab baru terlaksana ketika ia kuliah di UAI. Sejak semester 1 (satu) ia telah memutuskan untuk berjilbab. Sekalipun terdapat faktor-faktor ekstrinsik yang turut memperkuat keinginannya berjilbab, tetapi rasa sukanya pada model busana muslimah ini yang sebenarnya berpengaruh lebih besar. D merasa lebih nyaman dan beraktualisasi diri dengan berjilbab.
"Yang paling mempengaruhi proses saya berjilbab adalah diri saya sendiri yang ingin lebih dekat dengan Allah, dan ditambah dukungan org tua. Saya merasa nyaman ketika berjilbab." (Wawancara dengan D, Ahad, 28 Juli 2013).

Ketika ditanya pengalaman negatif dalam proses pengambilan keputusan berjilbab dulu, D mengaku tidak pernah mengalami perlakuan negatif terkait jilbab. Hanya saja, saat melihat sebagian muslimah berjilbab yang pakaian, perilaku, atau ucapan mereka kurang sesuai tak urung sempat membuatnya berpikir ulang untuk benar-benar berjilbab. Untunglah, motivasi intrinsik yang kuat membuatnya tetap kukuh berjilbab.

"Saat saya memakai jilbab di sebuah restoran saya melihat ada sekelompok wanita berjilbab yang merokok dan bermain kartu di sana. Saya yg samasama memakai jilbab merasa malu atas tindakan orang-orang itu...Namun, masih banyak wanita berjilbab yg memang berjilbab dengan benar karena Allah. Wanita yg tidak tulus berjilbab yang mempengaruhi saya ragu terhadap jilbab, dan wanita yang tulus berjilbab yang membuat saya ingin berjilbab serta bangga berjilbab."

Dari uraian di atas, terlihat bahwa motivasi instrinsik untuk berjilbab dalam diri D sebenarnya sudah kuat. Dan menemukan momentumnya dengan dukungan orang-orang dan lingkungan sekitarnya.

\section{Motivasi Ekstrinsik Subjek D}

Dalam keluarga besar D, tidak semua perempuan dewasanya berjilbab. Bude, tante, dan beberapa sepupunya sampai saat ini belum berjilbab. Ditambah pola keberagamaan keluarganya yang semula kejawen, tampaknya tidak mendukung motivasi intrinsik yang sejak SMP ada dalam diri D untuk berjilbab.

Namun seiring berjalannya waktu, sepulang kedua orang tua $\mathrm{D}$ dari ibadah haji yang mendorong beliau berdua lebih mendalami dan berusaha mengamalkan Islam dengan baik, $\mathrm{D}$ seperti menemukan dorongan ekstra untuk mewujudkan keinginannya berjilbab. Terlebih ketika akhirnya sang ibunda memutuskan berjilbab.

Keputusan kuliah di UAI, menurut D, menambah dorongan baginya untuk berjilbab. Dan ini mendapat dukungan penuh dari sang ibunda.

"Saat masuk kuliah di UAI, ibu mendukung saya belajar istiqamah berjilbab. Dimulai dengan berjilbab saat ke kampus, karena menurut ibu saya UAI merupakan lingkungan yang islami sehingga 
saya harus menghormatinya dengan berpakaian sopan. Juga sebagai wadah pembelajaran saya untuk berjilbab. Dan ibu saya berdoa agar dengan lingkungan yg mendukung saya bisa seutuhnya berjilbab." (Wawancara dengan D, Ahad, 28 Juli 2013).

Lingkungan UAI yang cukup islami, diakui D, memperkuat motivasinya untuk berjilbab. Temanteman kuliahnya banyak yang memberikan dukungan ketika D berjilbab. Apa yang mereka sampaikan tidak sedikit membuka cara pandang baru bagi $\mathrm{D}$ tentang manfaat jilbab; seperti bahwa ia lebih cantik ketika berjilbab, jilbab memberi rasa aman dan nyaman, jilbab membuat pemakainya terlindungi dari panas dan hujan, dan seterusnya.

Dari uraian tersebut, terlihat bahwa motivasi ekstrinsik -yang berasal dari luar diri karena adanya harapan-harapan tertentu, dapat berpengaruh signifikan terhadap tingkat motivasi intrinsik yang ada. D tetap memerlukan motivasi dari orang-orang terdekat agar ia bisa berjilbab sepenuhnya.

\section{Manfaat Berjilbab Subjek D}

Saat ditanya manfaat yang ia rasakan dengan berjilbab, D dengan yakin menjawab bahwa ia mampu lebih menjaga sikap dengan berjilbab. D merasa keputusannya berani berjilbab berarti dalam kesehariannya ia membawa nama baik Islam. Sehingga ia terdorong untuk mengontrol sikap dan lisannya.

Hubungan sosialnya, baik di lingkungan tempat tinggal maupun di kampus, juga tidak banyak berubah pasca keputusannya untuk berjilbab. Keluarga besar senang dengan keputusan D berjilbab, bahkan mereka mendoakan kelak ia bisa 'sepenuhnya' berjilbab.

Ketika disinggung tentang perbedaan interaksinya dengan lawan jenis antara sebelum dan setelah berjilbab, D jujur mengaku memang mempunyai pacar. Dan ternyata keputusan D berjilbab justru membuat sang pacar lebih menghormatinya.

\section{Gambaran Umum Subjek Y}

Y adalah mahasiswi semester 7 (Tujuh) di salah satu prodi Fakultas Sains dan Teknologi, Universitas Al Azhar Indonesia (UAI). Dikenal sebagai sosok tegar, mandiri, dan luwes dalam berinteraksi dengan teman-temannya dari kalangan mahasiswi maupun mahasiswa. Y cukup aktif, terutama dalam kegiatan-kegiatan Himpunan
Mahasiswa Teknik Industri (HMTI) UAI dan Ikatan Mahasiswa Teknik Industri (IMTI) seJakarta, UKM tari, dan sebagainya.

Y adalah anak pertama dari dua bersaudara. Bapaknya adalah karyawan Pertamina dan ibunya memilih sebagai ibu rumah tangga. Secara umum, keluarga $\mathrm{Y}$ adalah keluarga dengan keislaman yang cukup kuat dan komunikasi yang harmonis.

Gambaran ini bahkan ditangkap jelas oleh $\mathrm{F}$, teman dekat $\mathrm{Y}$, sebagaimana disampaikannya dalam suatu wawancara yang dilakukan pada hari Senin, 29 Juli 2013:

"Keluarganya secara umum adalah keluarga yang bahagia. Ketika saya berkesempatan bertemu dengan keluarganya, dari cara $Y$ bercanda dengan papanya, mamanya dan adik-adiknya menunjukkan keluarga itu keluarga yang bahagia. Dari kehidupan keagamaannya, keislaman keluarganya bisa dibilang kuat. Anak-anaknya selalu didorong shalat berjamaah, mengaji, dan papanya sangat terbuka."

$\mathrm{Y}$ mengenyam pendidikan dasar dan menengah pertama di sekolah-sekolah unggulan di daerah Indramayu. Namun kedua sekolah itu, menurut pengakuan $\mathrm{Y}$, biasa-biasa saja dalam menanamkan nilai-nilai keislaman kepada anak-anak didiknya. Tetapi setelah itu, Y melanjutkan jenjang SMU di salah satu SMU Islam ternama di ibukota yang terletak di Pejaten, cabang dari SMU yang sama di daerah Kebayoran Baru, Jakarta Selatan.

\section{Pengetahuan tentang Jilbab Subjek Y}

Ketika ditanya tentang beberapa sisi syariat Islam, terutama yang berhubungan dengan kewajiban seorang muslimah menutup aurat, $\mathrm{Y}$ dapat menjelaskan dengan cukup akurat. Misalnya, ia lebih berpandangan bahwa berjilbab adalah kewajiban agama (Islam), bukan sekadar budaya. Menariknya, Y mengidealkan jilbab semestinya membudaya di kalangan muslimah Indonesia.

"Sayangnya, walaupun mayoritas orang Indonesia muslim, tetapi berjilbab belum menjadi budaya." (Wawancara dengan Y, Sabtu, 27 Juli 2013)

Karena mengenyam pendidikan menengah atas di SMU yang kental bernuansa Islam, Y mengetahui dengan baik bahwa setiap muslim dan muslimah berkewajiban menutup aurat. Yaitu, bagian tubuh yang harus ditutupi, karena haram hukumnya dilihat lawan jenis.

"Batasan aurat bagi seorang muslim dari pusar sampai lutut. Sementara bagi muslimah adalah 
seluruh anggota tubuhnya, kecuali wajah dan telapak tangan," jelas Y.

Walaupun merasa belum seratus persen berjilbab dengan benar, Y sebenarnya menyadari bahwa standar jilbab yang sesuai dengan syariat adalah yang menutup aurat dan tidak membentuk anggota tubuh seorang muslimah.

Pengetahuan Y yang tergolong baik tentang syariat Islam, terutama mengenai kewajiban berjilbab, cukup berpengaruh membuatnya bertahan untuk terus istiqamah berjilbab. Dan ini menjadi faktor penting bagi $\mathrm{Y}$ untuk terus berproses berjilbab dengan benar.

\section{Motivasi Intrinsik Subjek Y}

Secara pribadi, Y mengakui tidak pernah membayangkan akan memilih berjilbab 'secepat ini'. Dan itu diketahui pula oleh kedua orang tuanya.

"Makanya, keluarga pada kaget waktu saya memutuskan berjilbab. Awalnya, saya ingin berjilbab saat saya menikah," ujar Y pada kesempatan wawancara tanggal 29 Juli 2013.

Y yang mulai berjilbab pada awal semester 3 (tiga) di UAI, mengakui bahwa niatan semula dalam dirinya hanya coba-coba. Selain karena kuatnya motivasi dari orang-orang dekatnya untuk berjilbab, ia juga pernah beberapa kali melihat model-model jilbab yang menarik. Jadi akhirnya ia terdorong untuk coba-coba. Hal ini dibenarkan oleh $\mathrm{F}$, teman dekat $\mathrm{Y}$, berdasarkan cerita $\mathrm{Y}$ kepadanya.

"Setelah teman-teman yang awalnya tidak berjilbab kemudian satu per satu mulai berjilbab, itu juga mendorong $Y$, dia sering suka memperhatikan model-model berjilbab; kenapa dia gak mulai berjilbab juga seperti teman-temannya yang baru mulai berjilbab."

Kadang-kadang pikiran untuk sesekali jalan-jalan tanpa berjilbab terlintas di benak Y. Tetapi, alhamdulillah, sampai sekarang ia masih bisa bertahan dan terus istiqamah.

Dari pemaparan di atas, terlihat bahwa motivasi instrinsik Y untuk berjilbab awalnya tidak dominan. Y memerlukan orang-orang dan lingkungan yang mendukung menguatkan motivasi intrinsik tersebut.

\section{Motivasi Ekstrinsik Subjek Y}

Dilahirkan dan dibesarkan di tengah-tengah keluarga dengan keislaman yang baik, diakui Y membuatnya terus didorong oleh keluarga intinya untuk berjilbab. Dan dalam proses dirinya berjilbab seperti sekarang, peran sang mama sangatlah besar.

F yang banyak tahu proses $\mathrm{Y}$ memutuskan berjilbab, bercerita cukup detail:

" $Y$ mulai berjilbab awal semester 3 (tiga) di UAI. Waktu itu, Y sedang liburan usai semester 2 (dua), mamanya membelikan banyak jilbab. Awalnya $Y$ tidak mau mengenakannya, mamanya bilang 'gak apa-apa disimpen aja dulu'. Ternyata di awal semester 3 (tiga), Y mau coba-coba memakai jilbab ke kampus. Akhirnya dari situ Y keterusan memakai jilbab sampai sekarang."

Tidak semua perempuan dewasa dalam keluarga besar Y berjilbab. Di antaranya, para tantenya baik dari pihak bapak maupun ibu Y. Namun ketika melihat $Y$ mulai coba-coba berjilbab, semua keluarga besarnya mendukung keputusan $\mathrm{Y}$. "Dukungan keluarga bagus, dibilang cantik, dan disuruh diteruskan," ujar Y pada wawancara tanggal 29 Juli 2013.

Motivasi eksternal dalam proses $\mathrm{Y}$ berjilbab juga datang dari teman-temannya di kampus. Menurut F, teman dekat $\mathrm{Y}$, semua temannya di kampus mendukung $\mathrm{Y}$ berjilbab. Tidak ada yang berkomentar negatif, bahkan teman-temannya yang belum berjilbab mendukung Y untuk konsisten.

Dari uraian di atas, terlihat bahwa motivasi ekstrinsik lah yang lebih dominan mendorong Y mulai berjilbab. Motivasi dari luar ini menguatkan motivasi intrinsik Y, sehingga dengan terus berada di tengah orang-orang dan lingkungan yang mendukungnya berjilbab akan terjadi pergeseran ke arah dominannya motivasi intrinsik Y.

\section{Manfaat Berjilbab Subjek Y}

Walaupun proses berjilbabnya diawali dengan 'coba-coba', Y mengaku merasa lebih aman dalam aktifitas sosialnya dengan pilihan pakaian yang tertutup seperti sekarang. Apa yang ia alami setelah memutuskan berjilbab, membuat $\mathrm{Y}$ menjadi semakin yakin untuk terus berjilbab.

Saat ditanya, kendala yang pernah dialami dengan berjilbab, Y mengaku hanya pada kegiatan-kegiatan yang lebih menekankan pada pergerakan fisik saja. Semisal kegiatannya dalam Unit Kegiatan Mahasiswa (UKM) Tari. Di luar hal tersebut, hampir tidak ada yang berubah.

Sementara terkait interaksi sosialnya, Y tetaplah sosok mahasiswi yang luwes dalam berinteraksi, 
tidak pernah pandang bulu, baik dengan temanteman dari kalangan mahasiswi maupun mahasiswa. $\mathrm{F}$ juga melihat tidak ada perubahan mencolok dalam pola interaksi $\mathrm{Y}$ antara sebelum dan setelah berjilbab, malah semakin positif.

"Sebelum $Y$ berjilbab dengan sifatnya yang supel dan mudah bergaul, $Y$ bergaul dengan siapa saja. Setelah berjilbab, $Y$ lebih bisa memilah bentuk pergaulan dengan lawan jenisnya. Y lebih bisa menyikapi hal-hal yang negatif." (Wawancara dengan F, Senin, 29 Juli 2013)

\section{Gambaran Umum Subyek F}

F adalah anak sulung dari 3 bersaudara, ia mempunyai 1 adik perempuan dan 1 adik laki-laki. F lahir di Jakarta pada tanggal 11 April 1990. Beragama Islam. Secara fisik, F mempunyai tinggi sekitar $160 \mathrm{~cm}$ dan berat $50 \mathrm{~kg}$. Berkulit putih dan bermata bulat. F juga berambut lurus dan panjang.

Ibunya adalah anak pertama dari 8 bersaudara yang berusia sekitar 48 tahun, Bekerja sebagai pengajar di salah satu yayasan Islam ternama di Jakarta. Beliau memiliki latar belakang keluarga yang islami. Adik-adik perempuan ibunya semua menggunakan jilbab termasuk beliau. Ayah F adalah anak pertama dari 4 bersaudara yang berusia sekitar 52 tahun. Beliau juga bekerja sebagai pengajar di salah satu Madrasah Tsanawiyah di Ciganjur. Beliau pun memiliki latar belakang Islam yang sangat kuat didikan dari orangtua beliau.

Terlahir dari keluarga yang kental dalam menjalankan syariat Islam, maka $\mathrm{F}$ juga dari TK sudah disekolahkan di sekolah bernuansa Islam oleh orangtua nya sampai pada Perguruan Tinggi. F diwajibkan mengenakan jilbab di SMP dan SMA dan saat itu F melakukannya karena terpaksa aturan dari sekolah.

Saat ini $F$ sedang menjalani pendidikan di Perguruan Tinggi bernuansa Islam di Jakarta. F kuliah pada semester 10 dan masih aktif dalam berbagai kegiatan kemahasiswaan.

\section{Pengetahun Mengenai Jilbab Subyek F}

Latar belakang keluarga yang mengajarkan agama sejak dini dan mengenyam pendidikan yang bernuansa Islam, membuat $\mathrm{F}$ mempunyai pengetahuan yang baik mengenai syariat Islam. Termasuk mengenai kewajiban berjilbab. $F$ berpendapat bahwa berjilbab merupakan syariat Islam dan kemudian menjadi budaya di daerah Timur karena sebagian besar masyarakat Timur beragama Islam.
"Berjilbab merupakan perintah serta anjuran bagi umat muslim untuk menutup aurat, dan itu merupakan sesuatu yang sudah menjadi sebuah budaya di Timur."

Selain itu, F juga memahami bahwa seorang muslimah yang sudah masuk akil baligh atau sudah datang bulan diwajibkan untuk menutup auratnya. Berikut kutipan wawancara pada hari Selasa, 30 Juli 2013:

"Seorang muslimah diwajibkan mengenakan jilbab setelah mereka memasuki akil baligh atau sudah mengalami masa datang bulan."

F pun paham sekali apa yang dimaksudkan dengan aurat itu sendiri. Dimana seorang perempuan harus menutupi seluruh bagian tubuh kecuali telapak tangan dan wajah agar terhindar dari syahwat lakilaki. Menurut F, jilbab yang dikenakan perempuan juga harus panjang menutupi dada, pakaiannya tidak pas di badan, dan tidak transparan. Walaupun F mengaku ketika berjilbab masih pakai pakaian ketat karena tidak mempunyai baju-baju yang sesuai. Terlihat juga pada keseharian $\mathrm{F}$ di kampus masih memakai pakaian yang pas di badan.

Hal ini juga sesuai dengan yang disampaikan A, sahabat F. Menurut A, F memahami bahwa berjilbab adalah kewajiaban bagi muslimah.

"Dia tau kewajiban mengenai jilbab, sempat bicara dengan saya karena pengaruh sekolah di....."

Pengetahuan $\mathrm{F}$ yang tergolong baik mengenai syariat Islam terutama mengenai kewajiban berjilbab, tidak membuat $\mathrm{F}$ dapat mengamalkannya dengan serta merta. Karena sampai saat ini F masih belum konsisten menggunakan jilbab. Pengaruh dari pengalaman semasa berjilbab dan komentar dari lingkungan sangat memberikan dampak bagi keputusan F mengenakan jilbab.

\section{Motivasi Instrinsik Subyek F}

Sejak duduk di bangku SMP, F sudah mengenakan jilbab, walaupun hanya ketika sekolah saja, "karena diwajibkan di sekolah, jadi terpaksa mengikuti" begitu F menanggapi ketika ditanyakan kapan mulai mengenakan jilbab.

Memakai jilbab ketika SMP dan SMA hanya sebatas kewajiban karena harus mengikuti aturan di sekolah. Namun, waktu memasuki dunia perkuliahan $\mathrm{F}$ mulai terpikirkan untuk mencoba memakai jilbab secara konsisten. Saat itu F ingin mengenakan jilbab karena melihat orang merasa nyaman dengan jilbab tersebut, dan tidak usah 
repot-repot mengurusi rambut. Namun hal ini tidak berjalan lama, setelah lebih kurang 1 bulan $\mathrm{F}$ membuka jilbabnya lagi dengan alasan tidak nyaman dengan omongan orang, terutama keluarga dan teman.

"Menurut mereka saya gak pantes pakai jilbab, udah gitu mereka berpikir saya udah gak bisa diajak gaul dan main lagi”

A sahabat $\mathrm{F}$ juga mengatakan bahwa teman-teman dekatnya juga memberikan komentar kepada $\mathrm{F}$ bahwa dia harus merubah perilakunya dulu sebelum berjilbab.

Sempat dibahas sama temen-temen deket, "ngapain pakai jilbab kalo perilaku loe belum berubah?"(Wawancara, Rabu 31 Juli 2013)

Dari uraian tersebut, terlihat bahwa motivasi instrinsik sangat susah ditimbulkan, karena harus datang dari dalam diri sendiri. $F$ belum merasakan adanya motivasi internal, karena $\mathrm{F}$ sendiri belum merasakan pada tahap nyaman ketika mengguunakan jilbab, masih terpengaruh oleh komentar dan respon dari lingkungan.

\section{Motivasi Ekstrinsik Subyek F}

Di keluarga besar $\mathrm{F}$, hampir semua perempuan memakai jilbab, hanya $\mathrm{F}$ dan adik perempuannya saja yang sampai saat ini belum berjilbab secara konsisten. Ketika awal masuk kuliah, orangtua $F$ sangat mendukung F untuk berjilbab, karena Ayah $\mathrm{F}$ tergolong keras dalam menerapkan ajaran agama di keluarga.

Seperti yang disampaikan A sahabat F, bahwa ayah F memang sangat keras dalam mendidik F. Sebagai anak pertama, $F$ diharapkan orangtuanya agar menjadi contoh bagi adik-adiknya.

"F sering curhat sama saya kalau ayahnya galak, kadang memukul dan berkata-kata kasar. F juga sempat pergi dari rumah karena keadaan tersebut. Walaupun sebenernya apa yang disampaikan ayahnya adalah hal yang benar"

Ibu F juga memakai jilbab dan guru di sekolah Islam. Ketika $F$ memakai jilbab, Ibunya sangat bahagia dan sering membelikan jilbab. Namun keluarga besar banyak yang memberikan respon tidak percaya.

"Ya ampuun...kaka pake jilbab? kayaknya mau kiamat nih! dengan ekspresi tidak percaya"

Komentar tersebut membuat F merasa tidak nyaman dan memutuskan untuk membuka jilbab lagi.
Kemudian ketika $\mathrm{F}$ mempunyai pacar yang menurut F mempunyai ilmu agama yang lebih baik dan sosok imam yang $\mathrm{F}$ dambakan, maka ketika diminta untuk memakai jilbab oleh pacarnya, $F$ langsung tergerak untuk berjilbab lagi.

"Setelah PKL, saya pakai jilbab lagi karena pacar saya yang minta untuk pakai jilbab, saya merasa nyaman dengan dia dan seperti sosok imam yang saya cari”

Namun berjilbab yang kedua kalinya ini juga tidak berjalan dengan konsisten. F membuka jilbab kembali setelah putus dari pacarnya. $F$ merasa sudah tidak ada lagi yang membuat dia ingin tetap mengenakan jilbab.

Setelah Hari Raya Idul Adha 2012, F tiba-tiba ingin memakai jilbab lagi, bertahan hanya sekitar 1 bulan, setelah itu membuka lagi karena $F$ merasa sikapnya belum sesuai dengan orang berjilbab yang selayaknya.

"Saya ingin memperbaiki dalam diri dulu, shalat masih kurang, tidak mendengarkan orangtua. Kalau udah bener baru pakai jilbab lagi..."

Hal lain yang menyebabkan $\mathrm{F}$ tidak dapat memakai jilbab secara konsisten disebabkan karena $F$ tidak menggunakan jilbab semenjak kecil sampai dewasa. Kalau ketika dewasa saja baru akan berjilbab sudah banyak godaan yang mengganggu.

A sahabat $\mathrm{F}$ juga membenarkan bahwa $\mathrm{F}$ sudah 3 kali lepas pasang jilbab selama kuliah. Menurut A, F masih labil dan sangat emosional karena pengaruh pola asuh orangtua yang keras juga.

"Menurut saya dia masih labil dan emosional, makanya belum konsisten pake jilbabnya juga".

F mengaku tidak ada pengaruh yang signifikan dari lingkungan UAI untuk keputusannya memakai jilbab. Hanya saja ada perasaan tidak enak hati atau sungkan ketika melihat teman yang dulu tidak berjilbab, sekarang sudah berjilbab.

Selain itu, menurut $\mathrm{F}$ bajunya saat ini pun tergolong kecil/ketat dan tidak pantas dipakai ketika menggunakan jilbab.

"Mama juga komplain pakai pakaian ketat dan suruh ganti. Tapi kalau pakai baju muslim takutnya dikomentarin kayak mau ke pengajian”

F juga mengungkapkan bahwa ada keinginan kedepannya untuk konsisten memakai jilbab, tetapi setelah bertunangan. 
"Di keluarga besar saya semua yang sudah menikah memakai jilbab"

Menurut $\mathrm{F}$ jilbab juga membatasi orang lain untuk bergaul atau dekat dengan $\mathrm{F}$, maka akan menyulitkan $\mathrm{F}$ untuk mempunyai banyak teman seperti biasanya.

Menurut A juga, F berjilbab awalnya karena cobacoba, kemudian diikuti dengan tuntutan keluarga dan pacarnya.

"Tuntutan keluarga yang mendorong $F$ berjilbab, serta pasangan karena setau saya pasangannya yang waktu itu cukup bagus pengetahuan agamanya. Juga untuk memperbaiki image kayanya, karena selama ini banyak yang berpandangan negatif kepada $F$ "

Dari uraian di atas, terlihat bahwa motivasi yang berasal dari luar diri karena adanya ganjaranganjaran yang diharapkan, tidak dapat bertahan lama apabila ganjaran tersebut sudah tidak ada. $\mathrm{F}$ memakai jilbab karena tuntutan orang lain di luar dirinya, seperti orang tua dan pacar. Ketika F sudah tidak menemukan penguatan dari orang-orang tersebut, maka motivasinya untuk berjilbab juga hilang.

\section{Manfaat Jilbab Subyek F}

Ketika beberapa kali mencoba berjilbab, F mengaku merasa lebih nyaman dibandingkan ketika tidak memakai jilbab.

"Orang yang melihat saya berjilbab, mereka jauh lebih bersikap sopan dan lebih menghargai saya,terutama lawan jenis".

Di awal menggunakan jilbab, $F$ masih berusaha menjaga sikap atau ucapannya, namun kembali lagi seperti semula karena belum menjalankannya atas dorongan dari dalam diri sendiri. Menurut F, sebenarnya saat ini ada keinginan untuk menggunakan jilbab secara istiqamah, namun ia ingin memantapkan hati dahulu dengan mulai merubah diri sedikit demi sedikit agar nanti ketika berjilbab sudah dapat menyesuaikan sikap dan perilaku.

"Keinginan untuk memakai jilbab secara permanen semakin besar, tapi saya pun ingin memantapkan hati dulu. karna saya sudah hampir $3 x$ bongkar pasang, jadi saya ingin benar-benar memantapkan hati dulu, agar tidak bongkar pasang jilbab lagi"

F juga sempat menyampaikan kepada A bahwa ia ingin memakai jilbab secara konsisten.
"Dia pengen sekali pakai jilbab terus, gak bukabuka lagi, tapi belum siap karena sikapnya masih belum berubah menjadi lebih baik"

Uraian di atas menggambarkan bahwa meskipun memperoleh manfaat dengan menggunakan jilbab, namun $F$ tetap belum memakai jilbab secara konsisten. F masih ingin memperbaiki diri dahulu agar dapat memantapkan hatinya.

Motivasi instrinsik sangat dibutuhkan agar $\mathrm{F}$ dapat isitiqamah berjilbab. Sementara motivasi ekstrinsik yang diperoleh selama ini seperti dukungan dari keluarga besar, orangtua, dan pacar hanya dapat membantu sesaat saja. Dibutuhkan penguat dari dalam diri supaya keinginan berjilbab tersebut bisa bertahan lama dan konsisten.

\section{ANALISIS ANTAR SUBYEK}

Analisis hasil penelitian berikutnya akan dibahas dengan analisis antar subyek berdasarkan pengetahuan mengenai jilbab, motivasi instrinsik, motivasi ekstrinsik, dan manfaat berjilbab.

\section{Pengetahuan Mengenai Jilbab}

\section{a. Kewajiban berjilbab}

Subyek D mempunyai pengetahuan yang cukup tentang kewajiban berjilbab. Hal ini dikarenakan pendidikan yang diterima di tingkat SD dan terutama-di SMP. Sedangkan subyek Y mempunyai pengetahuan yang baik mengenai kewajiban berjilbab bagi muslimah. Atmosfer keislaman keluarga dan pendidikan SMUnya mendorong semua itu. Begitupun dengan subyek F yang juga mempunyai pengetahuan yang baik mengenai kewajiban berjilbab bagi muslimah, karena latar belakang keluarga yang mengajarkan agama sejak dini dan mengenyam pendidikan yang bernuansa Islam mulai dari TK hingga Perguruan Tinggi.

\section{b. Batasan aurat}

Subyek D memahami dengan baik adanya perbedaan batasan aurat antara muslim dan muslimah. Walaupun tidak cukup akurat mengidentifikasikannya. Sementara Subyek Y memahami dengan baik adanya perbedaan batasan aurat antara muslim dan muslimah, termasuk perinciannya. Begitupula dengan Subyek F yang juga memahami bahwa aurat adalah bagian tubuh yang wajib ditutupi agar tidak mengundang syahwat. $\mathrm{F}$ juga paham bahwa pakaian muslimah yang sesuai dengan syariat Islam adalah yang 
menutupi dada, tidak ketat, dan transparan. Begitupun untuk batasan-batasan aurat antara muslim dan muslimah dapat dijelaskannya dengan baik.

\section{Motivasi Instrinsik}

Pada dasarnya subyek D memang ingin memakai jilbab karena merasa nyaman dan lebih dekat dengan Allah. Sementara Y memakai jilbab berawal dari coba-coba, dan lambat laun menemukan kenyamanan dari pilihannya ini. Subyek F ngin memakai jilbab berawal dari cobacoba dan ingin merasakan kenyamanan, namun $\mathrm{F}$ belum menemukan kenyamanan dari dalam dirinya dan kemudian melepas jilbab kembali.

\section{Motivasi Ekstrinsik}

Perbaikan keislaman keluarganya membuat D menemukan dorongan ekstra untuk berjilbab, terlebih setelah meneruskan kuliah di Perguruan Tinggi yang islami pula. Subyek Y mendapat dorongan dari keluarga, terutama ibunya, membuat Y memilih berjilbab jauh lebih awal dari rencana semula. Teman-teman kuliahnya juga memberikan dorongan yang positif. Dan motivasi ekstrinsik dari subyek $\mathrm{F}$ berasal dari tuntutan orangtua dan keluarga besar yang hampir semua sudah memakai jilbab. Serta terdorong atas permintaan pacar yang menginginkan $\mathrm{F}$ berjilbab. Tetapi setelah putus dengan pacarnya, F membuka jilbab kembali.

\section{Manfaat Berjilbab}

Manfaat berjilbab menurut subyek D membuatnya merasa lebih dekat dengan Allah, aman, dan nyaman. Pacar menjadi lebih menghargainya. Interaksi sosial juga tidak banyak berubah. Subyek Y merasa lebih aman dan nyaman dengan pakaian muslimah yang tertutup. Hubungan sosial juga tidak banyak berubah, bahkan menjadi lebih terarah dan positif. Dan menurut subyek F, mengenakan jilbab membuatnya lebih merasa dihargai dan dihormati, terutama oleh lawan jenis. Ia menjadi berusaha untuk menjaga sikap dan perilaku lebih baik walaupun belum konsisten.

\section{KESIMPULAN DAN SARAN}

\section{Kesimpulan}

Dari ketiga responden penelitian ini terlihat bahwa Subyek D, Y, dan F sama-sama mempunyai latar belakang pendidikan agama yang bagus, baik dari keluarga maupun pendidikan formal. Walaupun secara keseluruhan Subyek F lebih lama mengenyam pendidikan bernuansa Islam, mulai sejak TK sampai Perguruan Tinggi. Namun hal tersebut tidak dapat menjadi patokan utama seseorang akan memperoleh motivasi instrinsik untuk berjilbab. Karena dalam penelitian ini Subyek $F$ yang mempunyai pengetahuan agama yang baik dengan latar belakang sekolah agama yang lebih lama dibandingkan subyek lainnya, malah tidak dapat menemukan dorongan dari dalam dirinya secara sadar untuk menggunakan jilbab.

Subyek D dan Y masih terus konsisten menggunakan jilbab. Mereka merasa nyaman dengan menggunakan jilbab. Walaupun pada awalnya subyek Y hanya coba-coba ingin memakai jilbab, tapi lama kelamaan ia menemukan kenyamanan dengan pilihannya untuk berjilbab tersebut. Sedangkan subyek F saat ini sudah tidak berjilbab lagi, ia belum merasakan kenyamanan seperti yang ia harapkan. Berdasarkan hasil penelitian ini, terlihat bahwa subyek $\mathrm{D}$ dan $\mathrm{Y}$ mempunyai motivasi instrinsik untuk menggunakan jilbab, yaitu agar memperoleh kenyaman dalam dirinya. Sedangkan subyek F tidak mempunyai motivasi instrinsik yang kuat sehingga belum mencapai kenyamanan dalam dirinya seperti yang dia harapkan.

Ketiga subyek penelitian ini semuanya memperoleh dorongan dari keluarga untuk memakai jilbab. Subyek D dan $\mathrm{Y}$ juga mendapat semangat dari teman-teman kuliahnya untuk terus berjilbab. Subyek $\mathrm{F}$ pernah memutuskan berjilbab karena permintaan pacarnya, namun setelah putus dengan pacarnya $F$ kembali membuka jilbabnya. Berdasarkan hasil penelitian ini, ketiga subyek mempunyai motivasi ekstrinsik dari orangtua, teman, dan ada pula dari pasangannya. Namun ketika ganjaran yang diharapkan hilang, maka motivasi ektrinsik itu juga akan menghilang. Seperti yang terjadi pada subyek F, ketika putus dari pacarnya kemudian ia memutuskan untuk kembali membuka jilbabnya.

Semua subyek penelitian ini pada dasarnya memperoleh kenyamanan dan ketenangan setelah berjilbab. Mereka merasa lebih dihargai oleh lawan jenis dan berusaha menjaga sikap. Namun penghayatan dalam memaknai jilbab ini masih berbeda, sehingga pada Subyek F ia masih belum merasakan kenyamanan yang mendalam yang mendorongnya untuk konsisten menggunakan jilbab.

Berdasarkan hasil diskusi diatas dapat disimpulkan bahwa dua dari subyek penelitian ini yaitu subyek 
D dan Y mempunyai motivasi instrinsik untuk berjilbab, dan satu subyek yaitu $F$ belum mempunyai motivasi instrinsik yang mendalam ketika memutuskan berjilbab. Ketiga subyek dalam penelitian ini mempunyai motivasi ekstrinsik, yaitu dukungan dari luar dalam memakai jilbab seperti dari orangtua, keluarga, teman, dan pasangan. Namun hanya dua orang Subyek penelitian ini yang masih konsisten berjilbab, yaitu subyyek D dan Y, dimana mereka mempunyai motivasi intrinsik sekali ekstrinsik untuk terus berjilbab. Sementara subyek $\mathrm{F}$ sudah tidak berjilbab lagi karena tidak mempunyai motivasi instrinsik yang kuat dan motivasi ekstrinsiknyapun sudah berkurang.

\section{Saran}

Saran dalam penelitian ini adalah sebagai berikut:

Saran Teoritis

1. Penelitian selanjutnya diharapkan dapat dikombinasikan dengan pendekatan kuantitatif sehingga dapat menjangkau sampel penelitian yang lebih banyak.

2. Penelitian ini diharapkan dapat dilanjutkan dengan melibatkan orangtua sebagai partsipan untuk memperoleh informasi lebih dalam bagaimana sikap orangtua dalam melihat motivasi anaknya ketika memakai jilbab.

Saran Praktis

3. Bagi mahasiswa Universitas Al Azhar Indonesia yang sudah berjilbab dan berniat untuk mengenakan jilbab, diharapkan dapat menimbulkan motivasi instrinsiknya agar dapat konsisten dalam mengenakan jilbab dan menemukan kenyamanan dalam dirinya.

4. Bagi keluarga besar Universitas Al Azhar Indonesia diharapkan dapat menjadi sumber motivasi instrinsik bagi mahasiswa untuk memakai jilbab.

\section{DAFTAR PUSTAKA}

[1] A. Alatas, Revolusi Jilbab, Al-I'tishom, Jakarta, 2001.

[2] A. Nadia, Jilbab Pertamuku, Depok: Lingkar Pena Publishing, 2005.

[3] C. Wade, Tavris and Carol, Psikologi, Jakarta: Erlangga, 2009.

[4] L.A. King, Psikologi Umum, Jakarta: Salemba Humanika, 2010.

[5] F.E. Guindi, Jilbab: Antara Kesalehan, Kesopanan, dan Perlawanan, Jakarta: Serambi, 2003.

[6] D.S. Bahtiar. Berjilbab dan Tren Buka Aurat, Yogyakarta: Mitra Pustaka, 2009.

[7] Ruliana, Skripsi: Motivasi Siswa Memakai Jilbab di Sekolah, Malang: UIN Malang, 2010.

[8] G.A. Santoso. Royanto. R.M. Lucia, Teknik Penulisan Laporan Penelitian Kualitatif, Jakarta: LPSP3 UI, 2009.

[9] Saryono. M.D. Anggraeni, Metodologi Penelitian Kualitatif, Yogyakarta: Nuha Medika, 2010. 